\title{
MODA NA KULTURĘ - POMIĘDZY INDYWIDUALNOŚCIĄ A POWSZECHNOŚCIĄ w KULTURZE WSPÓŁCZESNEJ
}

\author{
Roksana Pilawska \\ Instytut Pedagogiki \\ Wydział Nauk Historycznych i Pedagogicznych \\ Uniwersytet Wrocławski \\ plac Uniwersytecki 1, 50-137 Wrocław \\ E-mail: roksana.pilawska@uwr.edu.pl \\ ORCID: https://orcid.org/0000-0002-5451-8249
}

\section{ABSTRAKT}

Cel. Dokonując interpretacji wybranych zjawisk społeczno-kulturowych, w poniższym artykule starałam się wykazać, że współczesna kultura popularna rozumiana jako przestrzeń codzienności, staje się specyficzną płaszczyzną aktywności pozwalającą na hybrydowe i spójne połączenie tego, co indywidualne z tym, co powszechne lub wręcz masowe. Moim celem - a zarazem najważniejszym pytaniem, wokół którego koncentrowałam swoje rozważania - było uchwycenie wzajemnych zależności pomiędzy „,ekonomizacją” wybranych elementów kultury, a kształtowaniem świadomości odbiorców i tworzeniem nowych, społecznie uprawomocnionych schematów funkcjonowania jednostki w przestrzeni społeczno-kulturowej.

Metoda. We wstępie artykułu przywołałam współczesne rozumienie kultury popularnej z perspektywy culturalstudies, jako przestrzeni konstruującej tożsamość jednostek. Następnie odwołując się do rozważań Zbyszko Melosika (2016), próbowałam scharakteryzować efekty i konsekwencje znanych procesów madonaldyzacji i disneizacji we współczesnej kulturze. W ostatniej części artykułu, odnosząc się do koncepcji Carla Cederstroma i Andre Spicera (2016), skonstruowałam własne pojęcie „Fit-Konsumentów"i odniosłam je do podstawowych założeń coachingu i psychologii pozytywnej.

Rezultaty. Przedstawione przeze mnie przykłady wybranych zjawisk kulturowych oraz przywołane koncepcje, wskazują na pewną zewnętrzną obligatoryjność i konieczność dokonywania wyborów przez współczesnych konsumentów - wyborów wynikających z kapitalizmu, który w założeniach miał zapewnić poczucie indywidualności i wolności poszczególnym członkom społeczeństwa.

Wnioski. Dokonując interpretacji i analizy wybranych zjawisk kulturowych, chciałam pokazać, że udzielenie odpowiedzi na pytanie - czy współcześnie to człowiek kreuje kulturę czy kultura kształtuje człowieka - jest nie tylko niemożliwe, ale także niepotrzebne. Istotą działań badawczo-naukowych powinno być dążenie do tego, by osoby związane z tematyką kultury popularnej (pedagodzy, andragodzy, 
kulturoznawcy etc.) poprzez praktyczne działanie lub konstruowanie trafnych, teoretycznych pytań, wspomagali kreowanie umiejętności krytycznego interpretowania elementów kultury i nadawania znaczeń u obecnych i przyszłych nadawco-odbiorców.

Słowa kluczowe: współczesna kultura popularna, tożsamość jednostki, styl życia

\author{
The fad for fit-culture - between individuality and universality in contemporary \\ culture
}

Abstract

Aim. In the article below I attempt to show that contemporary popular culture, understood as a space in everyday life, becomes a specific plane for activity, allowing a hybrid and coherent combination of that which is individual with that which is common or even mass. My aim - and at the same time the most important question around which I will concentrate my considerations - was to perceive the mutual relations between the "economization" of selected elements of culture and shaping the awareness of recipients and the creation of new, socially valid patterns of the functioning of the individual in the socio-cultural space.

Methods. In the introduction to the article, I recall the modern understanding of popular culture from the perspective of cultural studies - as a space forming the identity of individuals. Next, by referring to the thoughts of Zbyszko Melosik (2016), I move on to characterize the effects and consequences of the processes of macdonaldization and disneization in contemporary culture. Finally, to sum up the concept of Carl Cederstrom and Andre Spicer (2016), I construct my own concept of "Fit-Consumers" and reference them to the basic approaches of coaching and positive psychology.

Results. The examples of selected cultural phenomena and concepts which I have presented point to a certain external obligation and necessity for contemporary consumers to make choices - choices resulting from capitalism, which by assumption is supposed to ensure a sense of individuality and freedom to specific members of society.

Conclusions. In interpreting and analyzing selected cultural phenomena, I wanted to show that answering the question - whether today mankind creates culture or culture shapes mankind - is not only impossible but also unnecessary. The essence of scientific research should be striving for those connected with the subject of popular culture (pedagogues, andragologists, culture scholars etc.) through practical action or constructing apt, theoretical questions, to help in the creation of skills to critically interpret elements of culture and give meaning to current and future broadcastersrecipients

Key words: contemporary popular culture, individual identity, lifestyle

\title{
WsTęP
}

Szeroko rozumiana kultura od zawsze pełniła istotną rolę $\mathrm{w}$ procesie rozwoju danego społeczeństwa. To właśnie poprzez zachowane źródła historyczne: pisemne lub materialne, starożytne cywilizacje mogły zapisać się na kartach historii. Trudno 
byłoby współcześnie zrozumieć potęgę oraz osiąnięcia cywilizacyjne starożytnego Egiptu, gdyby nie zachowane monumentalne piramidy, które do dzisiaj fascynują nie tylko historyków i archeologów, ale także architektów, inżynierów oraz „zwykłych turystów". Od wieków, to dorobek historyczny, artystyczny, społeczny oraz techniczny świadczył o odrębności danego narodu lub grupy etnicznej na tle innych społeczeństw. Dawniej można było więc zaryzykować stwierdzenie, że to ludność danych narodów i grup stopniowo tworzyła swoją własna, unikatową kulturę, przekładająca się na obowiązujące style życia i wyznawane hierarchie wartości. Jednak współcześnie, $\mathrm{w}$ dobie rozwoju nowoczesnych technologii, powszechnego dostępu do mediów i Internetu, dominacji konsumpcyjnego stylu życia oraz wielości przedstawianych wzorów i wizerunków medialnych, prawdziwość tego stwierdzenia oraz jednoznaczne zdefiniowanie samego terminu kultury nie jest już tak proste.

Wcześniej dominujące postrzeganie kultury jako specyficznego czynnika tożsamości przynależnego do konkretnego narodu i wpływającego na jej członków, powoli traci swoich zwolenników zarówno w środowisku naukowym, jak i artystycznym. Uczestnictwo w "globalnym supermarkecie kultury", zachęca jednostkę do dokonywania samodzielnych i selektywnych wyborów pomiędzy charakterystycznymi elementami życia zaczerpniętymi z innych kultur, które - w jej odczuciu - będą odróżniać ją na tle innych osób (Mathews, 2005, s. 7). Według niektórych badaczy popularnej perspektywy kulturoznawczej culture studies, współczesna kultura podobna jest do mody, w której każdy może wybrać własną tożsamość kulturową - niczym ubranie lub model telefonu. Jean Francois Lyotard (1997) zauważa, że aktualna, eklektyczna kultura pozwala na słuchanie reggae, oglądanie westernów, noszenie ubrań w stylu retro, picie coca-coli oraz jedzenie tradycyjnych, lokalnych potraw jednocześnie.

Globalny rynek kulturowy (przypominający centrum handlowe) daje możliwość indywidualnego wyboru. $\mathrm{W}$ tym ujęciu globalizacja jest zazwyczaj przedstawiana jako pozytywne zjawisko ekspansji różnorodnych fragmentów kultury na rynek światowy, które mogą zostać wybrane przez określone grono zindywidualizowanych jednostek (świadomych konsumentów). Zdaniem Roberta Jay Liftona (1993, ss. 28-29) "każdy z nas w dowolnym momencie ma dostęp do wizerunków i idei pochodzących z dowolnego miejsca świata lub wywodzących się z dowolnego punktu historii ludzkiej kultury" - w efekcie tych możliwości kształtujące się „ja-ponowoczesne" (określane przez badacza mianem ,ja-proteuszowego") pozwala na nieustanne, płynne, nieograniczone konstruowanie siebie na nowo.

Jednak według Anthonego Giddensa (2002), powyższa możliwość wyboru sama w sobie narzuca pewne ograniczenia. W świecie, w którym różnorodne kultury, religie i style życia wzajemnie się przeplatają ów wybór zostaje zobligowany do konieczności i przymusu: nie mamy wyboru, musimy wybierać - co wydaje się zaprzeczeniem jego powyżej opisanej rangi związanej z kwestiami możliwości, świadomości, indywidualności i wyzwolenia. Wspomniany zakres sprawstwa oraz nieograniczone możliwości jednostki lub całego społeczeństwa w zderzeniu z globalnymi zjawiskami makdonaldyzacji i disneizacji stają się interesującym obszarem badań zarówno dla kulturoznawców, jak i pedagogów. Czy w dobie „multikulturowości” oraz związanych z nią sprzeczności można jeszcze mówić o własnej spójnej, charakterystycznej kulturze lokalnej lub narodowej? (Giddens, 2002). Celem poniższego artykułu nie jest 
jednoznaczne udzielenie odpowiedzi na to pytanie. Powołując się wybrane zjawiska społeczno-kulturowe o charakterze globalnym, chciałabym spróbować zarysować zakres i granice współczesnej tożsamości kulturowej oraz teoretycznie rozważyć związane z nią dylematy, możliwości oraz potencjalne zagrożenia.

\section{UPADEK STABILNEJ KULTURY}

W ostatnich latach dokonało się wiele przemian o charakterze społeczno-kulturowym. Nowoczesny świat nastawiony na przepływ informacji i innowacyjną technologię, różni się od realiów, w których dorastały poprzednie pokolenia. Coraz częściej naukowcy podejmujący próbę definicji kultury, rezygnują z dawniej dominującego jej humanistycznego rozumienia (odwołującego się wyłącznie do wybitnych osiagnnięć człowieka). Od kilku dekad popularność zyskuje szersza definicja, odnosząca się do całego kontekstu ludzkiej aktywności (Jakubowski, 2016). Na znaczeniu traci również pojmowanie kultury jako zjawiska łączącego ludzi w konkretnym miejscu na Ziemi. Wskazują na to słowa antropologa Roberta Brightmana (1995, s. 510), który twierdzi, że „choć przymiotnik kulturowy nadal pojawia się w funkcji orzecznika (...), to sformułowanie takie jak «kultura» ( w tym - R.P.) «kultura Kwakiutlów» czy «kultura Nuerów» spotyka się coraz rzadziej (...) (co ukazuje-R.P.) wątpliwości autora i jego samoświadomość". Obecnie żyjemy w epoce, w której poszczególne elementy popkultury stają się ramami interpretacyjnymi rzeczywistości. Niektórzy badacze zajmujący się powyższą problematyką uważaja, że stopniowo można mówić o powstawianiu "globalnej”, choć różnorodnej „kultury światowej”. W tym podejściu eksponowany jest aspekt lokalny, który wchodząc w relację z kulturą globalna, tworzy całkiem nowy, wyemancypowany podmiot (Melosik, 2016). Według innych powszechnie znanych badaczy, współczesne przemiany kulturowe to początek „Globalnej Wioski” (McLuhan, 2001) lub „Ery Elektronicznej” (Toffler, 1986).

Dynamicznie zmieniająca się przyszłość przestała być przewidywalna, przez co funkcjonowanie człowieka $\mathrm{w}$ zasobach antropologicznie rozumianej kultury nie jest łatwe (Jakubowski, 2001). Zasadniczym pytaniem stawianym przez wielu badaczy jest dylemat, jak ocenić współczesną różnorodność kultury popularnej, stanowiącej zupełnie nową formę przestrzeni, która łączy w sobie zarówno artystyczny i intelektualny dorobek społeczeństwa, jak i dochodowy biznes, w którym elitarne jednostki kierujące międzynarodowymi korporacjami upatrują źródła dochodu.

\section{Lokalna kultura w wersji take-away}

Próbując dokonać obiektywnej oceny współczesnych przekazów społeczno-kulturowych niejednokrotnie nie mogłam oprzeć się wrażeniu, że pomimo szerokiej gamy różnorodnych ofert medialnych, sama jakość prezentowanych wysokobudżetowych programów i filmów zeszła na dalszy plan. W nastawionej na szeroki odbiór popularnej kulturze audiowizualnej, najważniejszym wydaje się być wzbudzenie zainteresowania daną ofertą oraz jej dobra sprzedaż czyli klasyczny związek „popyt - podaż”. Potwierdzeniem powyższej tezy mogą stanowić liczne seriale paradokumentalne, które od kilku lat są obecne w programie każdej większej stacji telewizyjnej.

Analizując to zjawisko z drugiej strony, można przyjąć stanowisko zwolenników kultury popularnej twierdzących, że istnienie zjawisk kulturowych podlegających 
zależnościom ekonomicznym, które figurując na rynku stają się „produktem” dostosowywanym do oczekiwań społecznych, podważa konsumpcyjny charakter współczesnej kultury. Zdaniem Johna Fiske (2010) ludzie często korzystają z elementów kultury popularnej, by nadać im indywidualne znaczenie, tworząc tym samym własne zasoby kulturowe. Dynamicznie zmieniająca się kultura współczesna w tym ujęciu jawi się więc jako nowy, nieustannie zmieniający się konstrukt - hybrydowe połączenie indywidualności z powszechnością - oryginalnych, różnorodnych, lokalnych wytworów z wysokodochodowym przemysłem rozrywkowym.

Zasadność powyżej przedstawionej perspektywy staje się interesującym zagadnieniem, zwłaszcza w odniesieniu do przestrzeni współczesnych mediów. W dobie powszechnego dostępu do Internetu, wyraźna wcześniej granica pomiędzy rolą "nadawcy" i „,odbiorcy" w erze „neotelewizji”, coraz bardziej się zaciera lub wręcz już nie istnieje. Każdy - niezależnie od wieku, wykształcenia lub miejsca zamieszkania - może aktywnie uczestniczyć w kształtowaniu współczesnej kultury. Jednak mimo potencjalnie nieograniczonych możliwości, młodym, niedoświadczonym twórcom często trudno jest znaleźć odpowiednią „niszę" w przesyconej przestrzeni medialnej lub „przebić się" przez konkurencyjną ofertę wielkich stacji telewizyjnych i portali internetowych. Pomimo widocznej różnorodności ofert kulturowych, w większości przypadków rola odbiorców w procesie kreowania popkultury ogranicza się do selekcji odbieranych materiałów - w postaci przełączenia kanału telewizyjnego lub wejścia na inną stronę internetową.

Analiza różnorodnych forów i portali społecznościowych wykazuje, że istnienie

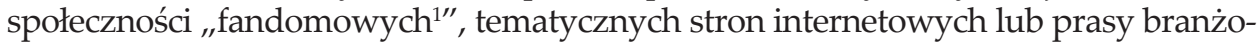
wej sprzyja indywidualnemu doborowi elementów oferty kulturowej przez odbiorcę (Jakubowski, 2014). Jednak z drugiej strony, przyglądając się najbardziej popularnym przestrzeniom kultury takim jak telewizja, moda lub film, można zaobserwować istnienie przeważających nurtów, których odbiorcami często są nieświadome jednostki, podążające za obecnym trendem. Dominujące w dziedzinie kultury media, nadal mają znaczący wpływ na odbiorców - przekazując i utrwalając w ich świadomości pewne normy, wartości, style życia i zachowania. Poprzez odpowiednio sformułowane komunikaty (między innymi reklamy) kreują nowe potrzeby i nadają znaczenie towarom użytkowym. Na skutek takich działań w społeczeństwie kształtowana jest „świadomość konsumpcyjna” - nakierowana na konieczność nabywania przedmiotów, „,kolekcjonowania" doznań oraz realizację własnych celów.

Przykładem systemów, które bardzo dobrze opisują powyższy mechanizm są dwie międzynarodowe korporacje - restauracje McDonald's i parki tematyczne Disneyland - obie nastawione na maksymalizację zysków przy sterowaniu zapotrzebowaniem na oferowane usługi. Zasięg wpływów obu firm jest między innymi widoczny w popularnonaukowych określeniach, takich jak „makdonaldyzacja” lub "disneizacja”, których od lat używa się w odniesieniu do przestrzeni społeczno-kulturowej.

1 Nowoczesne media, a zwłaszcza popularne portale społecznościowe, stały się miejscem tworzenia nowych wspólnot. Witold Jakubowski przywołuje tutaj znaczące zjawisko fandomu określające poczucie odrębności społecznej przez grupę fanów danego zespołu lub idola popkultury. Zob. W. Jakubowski (2014,s. 99). 
Do tych dwóch, szeroko omówionych w literaturze terminów chciałabym jeszcze dodać powszechną ",amerykanizację” życia społecznego. Symbole amerykańskiej kultury popularnej, będące równocześnie znakami firmowymi znanych marek są rozpoznawalne na całym świecie. Kawy serwowanej przez firmę Starbucks można spróbować w wielu lokalach znajdujących się w każdym większym europejskim lub amerykańskim mieście. Kurczaka oferowanego przez Kentucky Fried Chicken można zamówić w większości krajów - i to z bezpłatną dostawą do domu. Kultura jedzenia uległa globalizacji - już nie musimy jechać do Indii, by zakosztować prawdziwej indyjskiej kuchni - centra handlowe oferują nam szeroki repertuar dań ze wszystkich stron świata i to w przystępnej cenie. Bez wątpienia można dostrzec dwa nurty w tworzeniu "globalnej kuchni". Pierwszy z nich dotyczy upowszechniania strywializowanych, "sfastfoodowanych" i przystosowanych do europejskich gustów dań kuchni azjatyckiej. Często z oryginalnych, orientalnych składników zostaje jedynie posmak niektórych przypraw. Drugi trend, związany z tak zwaną ",kulturą hamburgera”, odnosi się do masowego eksportu amerykańskiego fast-foodu na gastronomiczne, lokalne rynki innych kultur (Melosik, 2016). W tym ujęciu cheeseburger i puszka coli jawią się jako symbole „kulturowego imperializmu”. Zdaniem krytyków, mieszkańcy Trzeciego Świata wraz ze spożywaniem hamburgera popijanego soft-drinkiem, „połykają" równocześnie zachodni styl życia i wpisane w niego wartości, wymazując fragmenty własnej lokalnej tożsamości.

Trudno jednak jednoznacznie ocenić postępujące zjawisko globalizacji smaków i potraw. Pomimo widocznej dominacji kulturowej zasady: anywhere USA (co można przetłumaczyć: gdziekolwiek się znajdziesz będziesz w USA), różnorodne konteksty kulturowe towarzyszące użytkowaniu amerykańskich produktów nadają im niejednokrotnie całkiem nowe znaczenia. W jednym z tekstów, Z. Melosik (2016) podaje przykład kuchni brazylijskiej lub kolumbijskiej, gdzie coca-cola jest popularnym składnikiem wzbogacającym smak oryginalnych, narodowych potraw. W tym przypadku, „amerykanizacja” mieszkańców Ameryki Południowej jest łączeniem lub wzajemnym przenikaniem praktyk kulinarnych. W tym kontekście warto przytoczyć również przykład jedzenia włoskiego, którego światowa popularność jest niezaprzeczalna. Jednak mimo to, jedzenie pizzy lub spaghetti (uważanych poniekąd za część światowego dziedzictwa kulturowego) przez mieszkańca Nowego Jorku, Rio de Janeiro, Londynu lub Paryża, nie jest postrzegane jako świadoma akceptacja włoskiego systemu wartości, prowadząca do wymazywania fragmentu amerykańskiej, brazylijskiej, angielskiej lub francuskiej tożsamości. Wręcz przeciwnie, w potocznym rozumieniu, wprowadzanie elementów kultur odmiennych uznawane jest za wzbogacenie doświadczeń kulturowych i tożsamości jednostki. Można więc zadać pytanie, dlaczego to akurat cheeseburger i coca-cola są obwiniane za manipulacje smakiem i symbol agresywnej amerykanizacji. Być może jest to spowodowane powszechnie przyjętym przeświadczeniem, że inwazyjna polityka zagraniczna i kulturowa Stanów Zjednoczonych od zawsze prowadziła do podporządkowania świata - czego przykładem może być coraz większa ilość amerykańskich "sieciówek" dominujących na europejskim, azjatyckim lub południowo-amerykańskim rynku (Melosik, 2016).

Przywołując powyżej opisane egzemplifikacje, moim celem nie jest udowodnienie, że negatywne nastawienie wielu badaczy do amerykańskiej homogenizacji i stan- 
daryzacji świata jest nieuzasadnione. Uważam jednak, że omawianiu wspomnianej problematyki powinna towarzyszyć nieustająca analiza pokazująca wady i zalety powyższego zjawiska oraz obejmująca wszystkie przykłady globalizacji, bez wstępnych założeń i uprzedzeń badacza.

\section{ERA McDonald's I Disneyland, CZYli „KAŻDY CZUJE SIĘ JAK W DOMU JEDYNIE W DWÓCH MIEJSCACH: W DOMU I AMERYCE"}

Rozpowszechnianie się tak zwanej restauracji take away związane jest ze wcześniej wspomnianym zjawiskiem makdonaldyzacji. George Ritzer (2009) opisując to zjawisko wymienił jego cztery charakterystyczne cechy, takie jak: efektywność, kalkulacyjność, przewidywalność oraz manipulację. Podczas wizyty w jednej z restauracji sieci McDonald, KFC lub innych "gastronomicznych imperatorów", klienci oczekuja, że dostana gotowy, prosty produkt $\mathrm{w}$ jak najszybszym czasie. Czują się bezpiecznie, ponieważ wiedza, czego mogą się spodziewać zarówno po obsłudze, jak i jakości serwowanych posiłków.

Podobne oczekiwania chcą zaspokoić u swoich odbiorców współczesne media. Wysokonakładowe, kolorowe czasopisma lub internetowe strony informacyjne podają skrócone wersje informacji i artykułów; wydawnictwa oferują mniej ambitnym uczniom streszczone wersje obowiązkowych lektur szkolnych, a biura turystyczne zachęcają do zakupu wycieczki dającej możliwość zwiedzenia trzech miast w cztery dni. Coraz większy dostęp do dóbr kultury popularnej - niezależnie do funduszy, czasu i miejsca jest zjawiskiem przemawiającym na rzecz komercjalizacji (Sugier-Szerpega, 2003), jednak „,kondensowanie” takich i podobnych ofert (dotyczących każdej dziedziny życia), może budzić wątpliwości. Podobne mechanizmy są także stosowane w przypadku telewizji. Przy wyborze ramówki do powszechnie emitowanej stacji komercyjnej - często bardziej od wartości merytorycznej nadawanych programów liczy się ich przewidywana oglądalność. Im bardziej dany projekt trafi w gusta „,szarej masy" odbiorców tym lepiej. Być może to jest przyczyną wspomnianego fenomenu seriali paradokumentalnych, w przypadku których widz nie tylko może się zidentyfikować z bohaterem, ale także pocieszyć się, że jego zwyczajne, codzienne problemy są nieznaczące $\mathrm{w}$ stosunku do sytuacji przedstawionych w serialu.

Tendencje we współczesnej kulturze popularnej związane są również ze zjawiskiem disneizacji, będącym częścią wcześniej omawianego procesu. Coraz więcej instytucji, korporacji medialnych czy sieci usług funkcjonuje wedle sposobu działania tematycznych parków Disneya zwanych Disneylandami. Według autora tego pojęcia Alana Brymana (1999), poza wymienionymi już cechami makdonaldyzacji, disneizację charakteryzuje również: tematyczność, zanikanie różnic w konsumpcji, handel gadżetami i dyspozycyjność emocjonalna. Tematyczność jest najbardziej widoczna na przykładzie branży restauracyjnej, w której fanom westernów proponuje się obiad w kowbojskim stylu, a osobom zwiedzającym dom Julii w Weronie do biletów dołącza się ulotkę restauracji połączonej z Shakespeare-shop. Większość tematycznych gastronomii bazuje na motywach: filmowych, muzycznych, sportowych, historycznych lub geograficznych. O ile, w niektórych przypadkach można mówić o słusznym nawiązaniu, to jednak w większości z nich stylizacja lokalu jest jedynie działaniem mar- 
ketingowym. Tematyzacji podlegają również wycieczki, hotele, przestrzeń miejska lub centra handlowe. Ostatni przykład jest także miejscem występowania ujednolicenia konsumpcji (inaczej zwanego dyferencjacją). Celowe łączenie różnych rodzajów aktywności, prowadzi do zacierania granic między robieniem zakupów (współcześnie coraz częściej określanym amerykańskim słowem shopping), a wizytą w parku rozrywki. Dokonując uogólnienia, można stwierdzić, że podstawowym założeniem zarówno Disneylandów, jak i firm wzorujących się na nich, jest teza, iż konsumpcja prowadzi do szczęścia.

Schemat funkcjonowania parków Disneya znajduje także swoje odzwierciedlenie na rynku książki i filmu, gdzie tworzone są „produkty totalne”, w przypadku których nakręcenie jednej produkcji, powoduje uruchomienie lawiny zasypujących rynek gadżetów, książek, zabawek i ubrań (wpływających na sukces finansowy producenta). Popularność danego artykułu przekłada się na kreowanie w społeczeństwie nowych trendów i potrzeb. Dobrym przykładem produktu totalnego, może być film animowany nakręcony przez Walt Disney Company w 1966 roku o przygodach sympatycznego Kubusia Puchatka i jego przyjaciół. Produkcja oparta na książce wydanej w 1926 roku okazała się sukcesem, na skutek czego przez ostatnie 40 lat na rynek trafiło 14 pełnometrażowych filmów animowanych i ponad 250 odcinków telewizyjnego serialu z zapominalskim misiem w roli głównej. Kubuś Puchatek od lat posiada wiernych fanów w każdym kolejnym pokoleniu, czego najlepszym przykładem może być ostatnia filmowa produkcja, aktualnie odnosząca komercyjny sukces na ekranach kin: Krzysiu gdzie jesteś? ${ }^{2}$ - przedstawiająca losy jednego z głównych bohaterów w dorosłym życiu. Postać Puchatka była również wcześniej wykorzystywana w literaturze dla dorosłych. W 1982 roku Benjamin Hoff cytując fragmenty książki, wydał popularny przewodnik o taoizmie - Tao Puchatka, a 10 lat później - Tao Prosiaczka (Szarzyński, 2007).

Powyżej opisane mechanizmy marketingowe, które można by sprowadzić do prostego hasła: „Kup a będziesz szczęśliwy!”, wydają się być nierozerwalnie połączone z dyspozycyjnością emocjonalną - elementem najbardziej kontrowersyjnym w opisywanym procesie disneizacji. Zgodnie $\mathrm{z}$ wpisaną $\mathrm{w}$ nią zasada, pracownik danej firmy, korporacji lub branży usługowej jest zewnętrznie zobligowany do odpowiedniego zachowania względem klienta - bez względu na samopoczucie czy sytuację życiową. Takie działanie ma na celu wzbudzenie $\mathrm{u}$ potencjalnego nabywcy/użytkownika poczucia wyjątkowości, przyjemności lub wręcz swobody - stworzenie atmosfery pozornie przypominającej niezobowiązujące spotkanie towarzyskie. To teoretyczne założenie, dopuszczające do pewnego stopnia manipulację klientem, zostało w pełni zaakceptowane i wpisane w zasady współczesnego "efektywnego" marketingu. Przedstawiciele wielu uznanych firm modowych, jubilerskich, kosmetycznych lub turystycznych, oferują swoim klientom zindywidualizowane produkty ekskluzywne, których proces zakupu (za odpowiednią opłatą) rośnie niemalże do rangi rytuału. Zastosowanie tej marketingowej zasady można zaobserwować również w branży rozrywkowej, gdzie

2 Interesującym jest, że film przedstawiający dorosłe życie jednego z głównych bohaterów słynnej powieści - poprzez zachowanie koncepcji filmowej, w której problemy życia codziennego subtelnie przeplatają się magicznym światem Stumilowego Lasu i ich niezwykłych mieszkańców wydaje się być powt.historią nie tylko dla dzieci, ale także (a może zwłaszcza) dla ich rodziców, którzy w napływie codziennych obowiązków nieco zapomnieli o cudownej aurze dzieciństwa. 
wybrane koncerty i wydarzenia kulturalne są połączone z późniejszymi wystawnymi bankietami dla osób posiadających specjalne zaproszenie. Powszechna chęć zaspokojenia potrzeby wyją̧tkowości, widoczna jest także w codziennym życiu, gdyż w prawie każdej sali kinowej można wykupić miejsca VIP, zapewniające więcej przestrzeni lub bardziej komfortowe siedzenia. Bogactwo indywidualnych ofert skierowanych do wybranej grupy klientów, staje się integralnym elementem współczesnego biznesu. Pomimo, że w większości przypadków, poczucie ekskluzywności wydaje się być pozorne, to jednak obecność takich ofert na rynku może świadczyć o rosnącej potrzebie społecznej, dotyczącej poczucia wyjątkowości i odmienności względem innych.

Wszystkie wymienione powyżej przykłady „ekonomizacji” poszczególnych elementów kultury popularnej, mogą prowadzić do smutnej refleksji, że współczesny świat biznesu i mediów pośrednio „wtłacza” jednostki w powszechny „wyścig” za: zdrowiem, młodościa, sukcesem i akceptacją innych. Pogoń za pozornym poczuciem szczęścia utożsamianym z konsumpcyjnym stylem życia i hedonistycznie rozumianą przyjemnościa, prowadzi do powszechnie aprobowanego społecznego „obłędu", w którym ludzkie ciała i umysły są wtłaczane w machiny kapitalizmu, a szerokie spektrum ludzkich emocji jest ograniczane przez powszechny odgórny obowiązek dobrego samopoczucia, którego szczegółowym opisaniem zajmę się poniżej.

„DON'T WORRY BY HAPPY"- o WSPÓŁCZESNYM POKOLENIU „FIT-KONSUMENTów"

Teraźniejszość wymaga od jednostki ciagłego samodoskonalenia oraz zdolności asymilacji do dynamicznie zmieniających się wymogów i oczekiwań społecznych. Na podstawie założeń proponowanych przez badaczkę Margaret Mead (2000), można sformułować stwierdzenie, że zadaniem stawianym przed nowym „postfiguratywnym pokoleniem" jest konieczność ciągłej aktualizacji wiedzy i umiejętności, które w przyszłości mogą zapewnić przewagę nad innymi w labilnych i niepewnych realiach. Podobne stanowisko przedstawiają Carl Cederström i Andre Spicer (2016) dodając, że styl życia przedstawicieli owego nowego pokolenia - których roboczo na potrzeby niniejszego tekstu chciałabym określić mianem „Fit-Konsumentów” - jest przede wszystkim determinowany przez zasady tak zwanej „,biomoralności”.

Współcześnie, celem odpowiednio formułowanych komunikatów medialnych staje się kreowane potrzeb, nadających kluczowe znaczenie towarom użytkowym. W efekcie tych działań, w umysłach odbiorców kształtowana jest świadomość konsumpcyjna (nakierowana na produkty i realizację własnych celów). Opisywana w publikacjach naukowych o współczesnej kulturze "tożsamość konsumenta”, wydaje się pełnić rolę modelu porządkującego wzajemną komunikację: polityków z wyborcami, instytucji z obywatelami, przedsiębiorstw i firm z klientami, autorów z czytelnikami czy mediów z odbiorcami (Szwed, 2003).

Szerzącej się, samonapędzającej „pętli komercjalizacji, w którą wydają się być „wplątani" współcześni Fit-Konsumenci, sprzyja także szeroka oferta prezentowanych nienaturalnie wyidealizowanych wizerunków. Znani i powszechnie lubiani „celebryci", masowo wydają autobiografie, wszechwiedzący eksperci udzielają zbawiennych rad w każdej dziedzinie życia, a coraz bardziej popularni wysportowani trenerzy zachęcają do jedzenia kiełków i crossfitu. Transmitowane za ich pośrednic- 
twem modelowe schematy zachowań kształtują określony wzór kobiecości i męskości, tym samym kodując nowy cel dążeń życiowych w podświadomości społecznej. Owa zmiana oczekiwań społecznych względem ról płciowych, widoczna jest najbardziej na przykładzie przekazów reklamowych, których celem jest wzbudzenie potrzeby zakupu konkretnego produktu u jak największej liczby odbiorców. Schematyczny model aktywnego, nastawionego na działanie, pewnego siebie mężczyzny, posiadającego odpowiednią prezencję oraz pozycję społeczną (o czym świadczą markowe ubrania, designerskie gadżety pozwalające na ciągły kontakt ze światem oraz duży samochód), obecny jest niemalże w każdym spocie reklamowym. Opisana schematyzacja, (którą w moim odczuciu można by nawet określić mianem „stereotypizacji”) nie dotyczy jednak wyłącznie płci męskiej. Przykuwająca uwagę uroda zewnętrzna i dobra kondycja fizyczna wydają się być współcześnie wpisane w kulturowy model silnej, nowoczesnej i niezależnej Super-Woman: idealnej żony i matki, zmysłowej kochanki oraz spełnionej zawodowo kobiety $\mathrm{w}$ jednym.

Znaczenie wszystkich przekazów społeczno-kulturowych formułowanych za pomocą mediów, uogólniając można sprowadzić do jednej zasadniczej funkcji - wykreowania wewnętrznego przekonania w umysłach odbiorców, że osiągnięcie sukcesu w każdej dziedzinie życia jest możliwe - wystarczy tylko szczypta motywacji, odrobina pozytywnego nastawienia, łyżeczka chęci i oczywiście zakup określonego reklamowanego produktu lub usługi. Dokonując generalizacji można przyjąć, że hasła głoszone przez trenerów personalnych i przedstawicieli coachingu, sprowadzają się do wspólnego przekazu: iż życiowym obowiązkiem każdego człowieka jest bycie szczęśliwym - a nawet więcej - że tylko będąc zadowolonym możemy osiągnąć sukces $\mathrm{w}$ aspekcie zawodowym, finansowym lub/i osobistym. W tym ujęciu elementem warunkującym szczęście i pozwalającym na odniesienie sukcesu jest przestrzeganie zdrowego stylu życia, rozumiane jako odpowiednie odżywianie, aktywność fizyczna, dbanie o wygląd zewnętrzny etc. Zdaniem specjalistów stosowanie się do zaleceń powyższej „recepty” ma zapewnić nie tylko akceptację społeczna, ale także podniesienie poczucia własnej wartości, na skutek osiągnięcia wspomnianego sukcesu lub po prostu lepszych wyników badań.

Jednoznaczna próba oceny tych powszechnie głoszonych haseł nie jest prosta. $\mathrm{Z}$ jednej strony nawoływanie do przestrzegania oczywistych zasad zdrowego żywienia i aktywności fizycznej, odciągających młodych ludzi od kolejek w fast-foodach, restauracjach typu take-away i kolejnych godzin spędzonych biernie przed komputerem, jest niezaprzeczalnie pozytywną inicjatywą. Jednak z drugiej strony, wytwarzająca się wokół nich atmosfera przymusu związana z akceptacją lub nieformalnymi sankcjami ze strony społeczeństwa, zaczyna do złudzenia przypominać fikcyjną opowieść o Żonach ze Stepford. Wszyscy wydają się być zobligowani do uczęszczania na jogę lub pilates, z własnej woli lub w ramach pakietu wykupionego przez firmę, która chce zwiększyć efektywność swoich pracowników i podnieść swoją renomę na konkurencyjnym rynku. Potrzeba ciągłego odczuwania szczęścia oraz konieczność dążenia do sukcesu poprzez nieustanne poprawianie własnej produktywności, są nam wmawiane od najmłodszych lat szkolnych - i to w taki sposób, aby każdy z nas traktował te społeczne dyrektywy jako własny, indywidualny i świadomy wybór. 
Na skutek owej „pętli przymusu samodoskonalenia” i wiary w nieograniczone możliwości ludzkiego działania, przekazywane „obowiązki życiowe” stają się uwewnętrznione w umyśle jednostki, na której ciąży odpowiedzialność za ich przestrzeganie. W momencie niepowodzenia lub chwilowego braku możliwości rozwoju, odczuwane poczucie winy, paradoksalnie jeszcze bardziej podświadomie wymusza podjęcie jakiejkolwiek aktywności - nawet o charakterze destrukcyjnym, ewidentnie szkodzącej naszemu ciału, o które troska, zgodnie z głoszonymi hasłami, powinna być dla nas najważniejsza.

Przekonanie, że każdy niezależnie od wszelkich przeciwności losu może osiągnąć szczęście warunkujące sukces, wydaje się najbardziej kontrowersyjnym założeniem coraz bardziej popularnego coachingu i tak zwanej psychologii pozytywnej - która pomimo znaczącego wpływu na rozwój psychologii przeznaczonej dla „,normalnych ludzi" (grupy względnie szczęśliwych członków społeczeństwa, pozostających w ogólnie przyjętych i uznanych normach psychicznych), nie jest do końca spójna w swoich teoretycznych podstawach. Czy narzucony związek przyczynowo-skutkowy pomiędzy zadowoleniem a sukcesem oznacza, że ludzie wpierw odnoszący sukces nie mogą już być szczęśliwi? Czy skoro zewnętrzne okazywanie własnego zadowolenia warunkuje akceptację społeczna, to powinno się pokazywać „zewnętrzne pozory szczęścia" dla polepszenia jakości relacji interpersonalnych? Czy w dobie konieczności ciągłej aktualizacji swoich kompetencji i pogoni za rozwojem, osiągnięcie autentycznego szczęścia jest $\mathrm{w}$ ogóle możliwe? I ostatnie, lecz chyba najważniejsze pytanie - czy funkcjonowanie zgodne z zasadami stylu życia uznawanego powszechnie za zdrowy, rzeczywiście jest jedynym sposobem do osiagnięcia stanu happy ever after? Co to oznacza być szczęśliwym?

Próbując udzielić jednoznacznej odpowiedzi na to pytanie, napotykamy kolejny paradoks. Z jednej strony mentor psychologii pozytywnej i autor wielu książek o zasadach pozytywnego myślenia Martin Seligman głosi, że dobre nastawienie oraz integracja "zdrowych cech" ze swoim, obecnym stylem życia wystarczą do osiągnięcia szczęścia - jest więc to dobrowolny wybór dostępny dla każdego, kto chce zmienić swoje nastawienie. Jednak z drugiej strony, ten sam autor twierdzi również, że prawdziwego szczęścia nie można odnaleźć w „narkotykach, seksie bez miłości, zakupach, masturbacji i telewizji" (Seligmann, 2005, s. 25). Zdaniem M. Seligmana prawdziwe szczęście to głębokie, wewnętrzne uczucie niedostępne dla wszystkich, wyzwalane na przykład w momencie kontaktu z tak zwaną „,kulturą wyższą”. Przyjęcie takiego stanowiska, zakłada równocześnie pewną selekcję społeczna, wedle której dostęp do „prawdziwego szczęścia” mogą mieć tylko nieliczni. Powstaje więc pytanie, czy poczucie spełnienia stanowi wyłącznie dobrowolny wybór i jest dostępne dla wszystkich, czy też jako cel wymagający od jednostki określonego poziomu wrażliwości i refleksyjności jest dostępny tylko dla nielicznych?

W mojej opinii, naukowa podstawa teorii psychologii pozytywnej, wykazując pewną dozę skostniałości i stygmatyzmu, traci na wiarygodności. Dokonywanie sztucznego podziału na kulturę „,wysoką" $\mathrm{i}$ „niską" (rozumianą jako kulturą masową - niegodną uwagi, dostarczającą banalnej przyjemności), czyli pominięcie elementów współcześnie rozwijającej się kultury popularnej jako hybrydowej przestrzeni przenikania aktywności jednostek z mechanizmami gospodarczo-marketingowymi, jest 
niepełnym i nieaktualnym ujęciem problematyki tego złożonego zagadnienia (Jakubowski, 2016).

\section{W POSZUKIWANIU WEWNĘTRZNEJ RÓWNOWAGI: „ŻYCIE TO NIE KSIĄŻKA KUCHARSKA PEENA GOTOWYCH RECEPT I PRZEPISÓW"}

W celu podsumowania powyższej refleksji, chciałabym powołać się na cytat Jeromego Brunera, który w jednej ze swych książek formułuje porównanie, że „życie rzadko daje się uporządkować na wzór książki kucharskiej, pełnej recept i przepisów" (2010, s. 34). We współczesnym świecie trudno jednoznacznie rozstrzygnąć spór, czy to człowiek kształtuje kulturę w której żyje, czy to może on sam podlega procesowi adaptacji do wymogów kulturowych. Współczesny świat wymaga od człowieka dokonywania trudnych wyborów. Media i kultura oferują wiele wzorów i fragmentarycznych obrazów rzeczywistości. W odróżnieniu od lat wcześniejszych nie ma stałych, utrwalonych społecznie wartości, do których jednostka mogłaby się odwołać podczas konfrontacji z licznymi przekazami społecznymi i kulturowymi. Z pewnością na kształtowanie potrzeb odbiorców i pewnych trendów kulturowych mają wpływ transnarodowe korporacje, które poprzez emitowanie filmów, programów, organizację eventów, popieranie akcji charytatywnych lub produkcję dóbr materialnych próbują zarobić fortunę. Oferowana przez nich propozycja kultury pełnej przyjemności zabawy i beztroski jest bardzo kusząca dla odbiorców. Teksty słyszane codziennie w spotach reklamowych wpływają na nasze wybory, podpowiadając jak żyć, w co się ubrać czy co zjeść. To pewna konkretna grupa osób decyduje o tym, jakie filmy i programy będą wyemitowane w naszych telewizorach. Świadczyłoby to o biernym procesie odbierania przejawów kultury przez zmanipulowanych odbiorców. Jednak, czy to nie my sami budujemy przedstawianą nam ofertę programów, filmów i utworów, ulegając współczesnym trendom i modzie na lekką i łatwą w odbiorze „kulturę", której celem jest wyłącznie rozrywka? Decydując się na oglądanie lub czytanie produktów popkultury, sami przyczyniamy się do dominacji międzynarodowych koncernów i stopniowego zanikania kultury lokalnej. Istotne więc jest, by zarówno pedagodzy, jak i andragodzy lub osoby chcące zasłużyć na miano prawdziwych trenerów personalnych i coachów, potrafili odróżnić sztucznie kreowane potrzeby (w których elitarne jednostki upatrują źródła dochodu), od realnych prób osiągnięcia wewnętrznego, autentycznego szczęścia poprzez indywidualne poszukiwanie życiowej równowagi i zbalansowanej przyjemności (Cederström, Spicer, 2016).

\section{Biblografia}

[1] Brightman, R. (1995). Forget Culture: Replacement, Transcendence, Relexification [Zapomnij o kulturze: Zamiana, Transcendencja, Releksyfikacja] Cultural Anthropology 4 (10), 509-546.

[2] Bruner, J. S. (2010). Kultura edukacji. Warszawa: Universitas.

[3] Bryman, A. (1999). The Disneyization of Society [Disneyizacja społeczeństwa], The Sociological Review 47 (1), $25-47$.

[4] Cederström, A., Spicer, A. (2016). Petla dobrego samopoczucia. Warszawa: Wydawnictwo PWN.

[5] Fiske, J. (2010). Zrozumieć kulture popularna. Kraków: Wydawnictwo Uniwersytetu Jagiellońskiego.

[6] Giddens, A. (2002). Nowoczesność i tożsamość: "Ja" i społeczeństwo w epoce późnej nowoczesności. Warszawa: Wydawnictwo PWN.

[7] Jakubowski, W. (2001). Edukacja i kultura popularna. Kraków: Oficyna Wydawnicza Impuls. 
[8] Jakubowski, W. (2014). Media i kultura popularna jako obszar studiów nad edukacją. Studia Edukacyjne (30), 91-108.

[9] Jakubowski, W. (2016). Pedagogika popkultury - prolegomena. W: W. Jakubowski (red.), Pedagogika kultury popularnejteorie, metody i obszary badań (ss. 15-29). Kraków: Oficyna Wydawnicza Impuls.

[10] Lyotard, J. F. (1997). Kondycja ponowoczesna: Raport o stanie wiedzy. Warszawa: Fundacja Aletheia.

[11] Mathews, G. (2005). Supermarket kultury. Warszawa: Państwowy Instytut Wydawniczy.

[12] McLuhan, M. (2001). Wybór tekstów. Poznań: Zysk i S-ka.

[13] Mead, M. (2000). Kultura i tożsamość. Studium dystansu międzypokoleniowego. Warszawa: Wydawnictwo PWN.

[14] Melosik, Z. (2016). Kultura popularna w globalnym świecie: ukryty program czy "anythinggoes"?. W: W. Jakubowski (red.), Pedagogika kultury popularnej - teorie, metody i obszary badań (ss. 29-49). Kraków: Oficyna Wydawnicza Impuls.

[15] Ritzer, G. (2009). Makdonaldyzacja społeczeństwa. Warszawa: Muza.

[16] Seligmann, M. (2005). Prawdziwe szczesście. Psychologia pozytywna a urzeczywistnianie naszych możliwości trwałego spetnienia. Poznań: Media Rodzina.

[17] Sugier-Szerpega, A. (2003). Mcdonaldyzacja życia i disneizacja w kulturze. W: R. Szwed (red.), Społeczeństwo wirtualne. Spoteczeństwo informacyjne (ss. 111-126). Lublin: Wydawnictwo KUL.

[18] Szarzyński, S. (2007). Piąta woda po Puchatku. Polityka (2) (2587), 60-64.

[19] Szwed, R. (2003). Wprowadzenie. Mediatyzacja społeczeństw. W: R. Szwed (red.), Społeczeństwo wirtualne. Społeczeństwo informacyjne (ss. 7-23). Lublin: Wydawnictwo KUL.

[20] Toffler, A. (1986). Trzecia fala. Warszawa: Państwowy Instytut Wydawniczy. 